EDUKACJA MIĘDZYKULTUROWA

2016, nr 5

ISSN 2299-4106

Dorota Dolata

\title{
„Pytania o Inność. \\ Inny w moich oczach, Ja w oczach Innego". Cieszyn, 15 grudnia 2015 roku
}

15 grudnia 2015 roku w Uniwersytecie Śląskim w Katowicach, na Wydziale Etnologii i Nauk o Edukacji w Cieszynie odbyła się pod patronatem J.M. Rektora niniejszego uniwersytetu prof. zw. dr. hab. Wiesława Banysia II Międzynarodowa Konferencja Naukowa zatytułowana „Pytania o Inność. Inny w moich oczach, Ja w oczach Innego", zorganizowana przez członków Koła Naukowego Edukacji Międzykulturowej, Zakład Pedagogiki Ogólnej i Metodologii Badań oraz Zakład Pedagogiki Społecznej i Edukacji Międzykulturowej. W organizacji przedsięwzięcia udział wzięli również: dr hab. prof. UŚ Ewa Ogrodzka-Mazur, dr hab. prof. UŚ Eugenia Smyrnova-Trybulska, dr hab. Barbara Grabowska, dr hab. Alina Szczurek-Boruta, dr hab. Anna Szafrańska-Gajdzica, dr Barbara Chojnacka-Synaszko, dr Katarzyna Jas, dr Łukasz Kwadrans, dr Pavlo Miroshnychenko, dr Alla Petrenko-Lysak, dr Renata Stefańska-Klar, dr Anna Studenska, mgr Aleksandra Gancarz, mgr Karolina Papiorkowska-Dymet, Łukasz Matusiak, Anastasiya Musokhranova, Agnieszka Suchy, Anton Dragomiletskii oraz Tulski Państwowy Uniwersytet Pedagogiczny im. L.N. Tołstoja. Niniejszej Konferencji przyświecała myśl przewodnia autorstwa Emmauela Levinasa: Skoro inny patrzy na mnie, to jestem za niego odpowiedzialny, nawet jeśli w jego oczach nie podjałem żadnych zobowiązań. Obrazuje ona częściowo dynamicznie zmieniającą się rzeczywistość społeczną, w której coraz częściej wchodzimy w interakcje z „Innymi”, czyli prościej ujmując, jednostkami różniącymi się od nas, które z tego powodu są określane jako odmienne. Kryterium „inności” jednak jest dla każdego człowieka różne, dlatego rozważania podjęte podczas konferencji miały charakter interdyscyplinarny, obejmując swym zasięgiem różnorodne wątki wzbogacające jego tematykę. Przedsięwzięcie to stanowiło płaszczyznę wymiany poglądów i opinii zarówno teoretyków, jak i praktyków różnych dziedzin naukowych, dzięki czemu była ona miejscem bogatej wymiany wiedzy z różnych obszarów tematycznych równocześnie koncentrujących się wokół problematyki ujmowania oraz przedstawiania tytułowego „Innego”. 
W konferencji udział wzięło ponad kilkadziesiąt prelegentów reprezentujących ośrodki akademickie zarówno z terenu całej Polski, jak i z Ukrainy, Białorusi i Rosji.

Konferencję otworzyli kolejno: prof. dr hab. Zenon Gajdzica - dziekan Wydziału Etnologii i Nauk o Edukacji w Cieszynie; dr hab. Urszula Szuścik - dyrektor Instytutu Nauk o Edukacji Wydziału Etnologii i Nauk o Edukacji w Cieszynie; dr hab. Barbara Grabowska i dr hab. Alina Szczurek-Boruta - opiekunki Koła Naukowego Edukacji Międzykulturowej. Niniejsze grono podziękowało za przybycie zaproszonych gości oraz prelegentów, nadmieniając, że jest to drugie tego typu przedsięwzięcie, które równocześnie cieszy się dużym zainteresowaniem.

W sesji plenarnej wystąpili kolejno: Michalina Pierchała (Uniwersytet Śląski w Katowicach; mgr Marta Putyra oraz mgr Elżbieta Ogierman (Uniwersytet Śląski w Katowicach), mgr Sylwia Jankowy (Uniwersytet Wrocławski). Wystąpienia wymienionych powyżej prelegentów wprowadziły słuchaczy w problematykę „Innego”, która obejmuje obszar wielu różnych dyscyplin naukowych oraz zróżnicowanych sytuacji społecznych.

Podczas konferencji łącznie było dziesięć paneli. Po każdym z nich następowała przerwa umożliwiająca słuchaczom oraz prelegentom podjęcie dyskusji nad prezentowanymi wątkami oraz rozwianie potencjalnych wątpliwości z nimi związanych. Tak duża liczba różnorodnych tematycznie sekcji świadczy o wysokim zainteresowaniu konferencją oraz o tym, że stanowiła ona płaszczyznę spotkania naukowców i teoretyków całego wachlarza dyscyplin naukowych i obszarów tematycznych.

Pierwszy panel zatytułowany został Etniczność i narodowość i podzielony był na dwie części. Pierwszej z nich przewodziły dr hab. Barbara Grabowska oraz Karolina Sibiga, a referaty wygłosiło łącznie pięciu prelegentów: Anton Saifullayeu (Uniwersytet Warszawski); Agnieszka Wojciechowska (Wyższa Szkoła Oficerska Wojsk Lądowych we Wrocławiu); Łukasz Matusiak (Uniwersytet Śląski w Katowicach); mgr Marlena Sędłak (Uniwersytet Papieski Jana Pawła II w Krakowie) oraz dr hab. Barbara Grabowska (Uniwersytet Śląski w Katowicach), których referaty oscylowały wokół zagadnień związanych z szeroko rozumianą innością w kontekście zróżnicowania kulturowego, etnicznego, a w szczególności w kontekście sąsiedzkich relacji narodowych.

Kolejnej części niniejszej sekcji tematycznej przewodziły dr Aniela Różańska oraz Katarzyna Szolc. Swoje wystąpienia zaprezentowało łącznie sześciu prelegentów: dr Łukasz Kwadrans (Uniwersytet Śląski w Katowicach); mgr Aleksandra Matyja (Uniwersytet Wrocławski); Natalia Maria Łozińska 
(Uniwersytet im. Adama Mickiewicza w Poznaniu); dr Marcin Kluzik oraz mgr Kinga Alicja Kowalik (Uniwersytet Pedagogiczny w Krakowie); mgr Katarzyna Bolęba-Bocheńska (Uniwersytet Jagielloński). Autorzy zobrazowali, w jaki sposób może być prezentowany oraz postrzegany „Inny” w realiach zróżnicowania kulturowego. Niektórzy prelegenci odnieśli swoje rozważania do zrealizowanych przez nich badań, których wynik stanowił kanwę ich referatów.

Równolegle czasowo odbywały się inne sekcje tematyczne: „Niepełnosprawność (I)”; „Niepełnosprawność (II)”; „Wykluczenie”; „Literacko-filozoficzne wymiary inności (I)”; „Literacko-filozoficzne wymiary inności (II)”.

Sekcji „Niepełnosprawność (I)” przewodziły dr Renata Stefańska-Klar, dr Ilona Fajfer-Kruczek oraz Marlena Stradomska. Swoje referaty miało zaprezentować pięcioro prelegentów, jednak ze względu na nieprzybycie dwójki z nich (mgr Magdalena Juźwik z Uniwersytetu Warszawskiego oraz mgr Joanna Świątek z Instytutu Slawistyki Polskiej Akademii Nauk), czynny udział w niniejszej sekcji tematycznej wzięły: mgr Marta Kierska (Uniwersytet Śląski w Katowicach); Joanna Kądziołka oraz Klaudia Rosiek (Uniwersytet Pedagogiczny w Krakowie); Karolina Wita-Banaszak oraz Wioletta Witkowska-Mucha (Uniwersytet Pedagogiczny w Krakowie). Rozważania tej grupy tematycznej oscylowały wokół niepełnosprawności postrzeganej w różnych aspektach oraz sytuacjach społecznych, zarówno w kontekście medialnym, artystycznym, jak również stereotypowego postrzegania niniejszych jednostek.

„Niepełnosprawności (II)" przewodziły dr Urszula Klajmon-Lech oraz dr Sylwia Wrona i Kinga Strządała, a czynny udział wzięło sześciu prelegentów: mgr Magdalena Jakubczak (Uniwersytet Jagielloński); mgr Dorota Burczyc (Uniwersytet Wrocławski); mgr Dorota Szulc (Akademia Górniczo-Hutnicza w Krakowie); dr Renata Stefańska-Klar (Uniwersytet Śląski w Katowicach); mgr Jerzy Norbert-Grzegorek (Uniwersytet Szczeciński); dr Ilona Fajfer-Kruczek (Uniwersytet Śląski w Katowicach). Prelegenci tej sekcji tematycznej przenieśli słuchaczy w świat percepcji osób niepełnosprawnych w różnych obszarach: medialnym, wirtualnym, w kontekście literatury i tańca. Wskazali tym samym, jak szeroki wachlarz tematyczny może zostać poruszony w związku z podjętą tematyką osób niepełnosprawnych.

Równolegle czasowo, w godzinach porannych, zrealizowane zostały trzy inne sekcje tematyczne: „Wykluczenie” oraz „Literacko-filozoficzne wymiary inności (I)”. Drugi z wymienionych bloków podzielony był na dwie części.

Sekcja „Wykluczenie” była moderowana przez mgr Tomasza Gebela oraz Patrycję Gawlik, którzy zapraszali kolejno czterech prelegentów niniejszej 
sekcji: mgr. Mariusza Janika (Uniwersytet Wrocławski); Aleksandrę Piotrowską (Uniwersytet Opolski); mgr Natalię Ulaniecką (Uniwersytet im. Adama Mickiewicza w Poznaniu) oraz Dorotę Dolatę (Uniwersytet im. Adama Mickiewicza w Poznaniu). W niniejszej sekcji tematycznej można było spotkać „Innego” w płaszczyźnie problematyki miasta Łodzi, jednostek orientacji homoseksualnej, kobiet cierpiących na chorobę nowotworową oraz języka osób bezdomnych.

W sekcjach „Literacko-filozoficzne wymiary inności (I) oraz (II)” wystąpiło łącznie dziesięcioro prelegentów. Podczas tego panelu słuchacze mieli okazję zapoznać się bliżej z problematyką „Innego” między innymi w kontekście reportażu, zaburzeń osobowości czy twórczości różnych wybitnych jednostek, a umożliwili to następujący prelegenci: mgr Karolina Papierkowska-Dymet (Uniwersytet Jagielloński); Agnieszka Suchy (Uniwersytet Śląski w Katowicach); mgr Patrycja Kowalik i mgr Patrycja Stroka (Uniwersytet Śląski w Katowicach); mgr Katarzyna Szkaradnik (Uniwersytet Śląski w Katowicach); Przemysław Szajca i Magda Maksymowicz (Uniwersytet Mikołaja Kopernika w Toruniu); mgr Alicja Soćko-Mucha (Uniwersytet Jagielloński); mgr Katarzyna Bondarenko (Uniwersytet Jana Kochanowskiego w Kielcach); mgr Angelika Maria Małek (Uniwersytet Papieski Jana Pawła II w Krakowie).

Po wymienionych powyżej porannych sekcjach tematycznych zaproszono zarówno gości, jak i prelegentów na obiad, podczas którego wszyscy uczestnicy, w kameralnej atmosferze, mieli okazję zapoznać się oraz wymienić spostrzeżeniami i doświadczeniami związanymi z wiodącą tematyką niniejszej konferencji.

Sekcja zatytułowana „Varia Socium”, została podzielona na dwie części. Pierwszej przewodzili dr Łukasz Kwadrans oraz Łukasz Matusiak, a drugiej mgr Sylwia Ryszawy oraz Kinga Banot. Łącznie w sekcjach wystąpiło dziesięciu prelegentów: Magdalena Koperska (Uniwersytet Jagielloński); mgr Oksana Rybak (Lwowski Uniwersytet Narodowy im. Iwana Franki); mgr Dorota Dolata (Uniwersytet im. Adama Mickiewicza w Poznaniu); dr Alla Petrenko-Lysak (Kijowski Uniwersytet Narodowy im. Tarasa Szewczenki); mgr Anna Ceglarska (Uniwersytet Jagielloński); dr Svetlana Filippova (Tulski Państwowy Uniwersytet Pedagogiczny im. L.N. Tołstoja); mgr Tomasz Gebel (Uniwersytet Śląski w Katowicach); dr Pavlo Miroshnychenko (Kijowski Uniwersytet Narodowy im. Tarasa Szewczenki); Emilia Przeor (Uniwersytet im. Adama Mickiewicza w Poznaniu); mgr Mirosława Jackowicz-Korczyńska (Uniwersytet Gdański). Problematyka poruszana podczas wystąpień wymienionych prelegentów oscylowała wokół dyskursu historycznego, jednostek 
orientacji homoseksualnej oraz ich postrzegania w społeczeństwie, jak również rodzinnego, subkultur młodzieżowych, transgresji, percepcji społecznej.

Kolejna sekcja, która również odbyła się w porze popołudniowej, zatytułowana została „Inny jako podmiot oddziaływań edukacyjnych”. Prowadziły ją dr Barbara Chojnacka-Synaszko, dr Katarzyna Jas oraz mgr Anna Wojtas, które zapraszały do wygłoszenia swoich referatów siedmioro prelegentów: dr hab. Alinę Szczurek-Borutę (Uniwersytet Śląski w Katowicach); mgr Natalię Chrobak (Uniwersytet Jagielloński); Katarzynę Szolc (Uniwersytet Śląski w Katowicach); Anastasię Musokhranovą (Białoruski Państwowy Uniwersytet Pedagogiczny im. M. Tanka); dr Anitę Czerwińską (Gimnazjum nr 3 w Cieszynie); Karolinę Sibigę oraz Aleksandrę Sowę (Uniwersytet Śląski w Katowicach). Wątki podejmowane w ramach tej sekcji tematycznej dotyczyły głównie postrzegania „Innego” w obszarze różnych instytucji społecznych, które w mniejszym bądź w większym stopniu mają styczność z procesem edukacji jednostki.

Po sekcjach tematycznych, które odbyły się późnym popołudniem, zaproszono gości na sesję posterową, podczas której miało okazję zaprezentować swoje plakaty piętnaścioro przedstawicieli różnych ośrodków akademickich: dr Barbara Chojnacka-Synaszko (Uniwersytet Śląski w Katowicach): Poznawanie i doświadczanie Innego osadzone w sferach (obszarach) życia codziennego; dr Katarzyna Jas (Uniwersytet Śląski w Katowicach): Inny świat - choroba Alzheimera jako przyktad niepetnosprawności osób starzejacych się; mgr Angelika Laskoś (Dolnośląska Szkoła Wyższa we Wrocławiu): Świat widziany w krzywym zwierciadle - dyskurs inności w aspekcie chorób psychicznych; mgr Sylwia Ryszawy (Uniwersytet Śląski w Katowicach): Kobieta w obliczu inności, czyli „męski” sport w kobiecym wydaniu; mgr Olga Tunkiewicz (Uniwersytet Szczeciński): Inny świat, inny „ja” - odmienność osób z zaburzeniami ze spektrum autyzmu; mgr Anna Twardzik (Uniwersytet Śląski w Katowicach): Praca w grupie zróżnicowanej kulturowo - wyzwanie czy problem dla nauczyciela?; mgr Anna Wojtas (Uniwersytet Śląski w Katowicach): Inność w twórczości studenta $z$ niepetnosprawnością; mgr Danuta Chorzempová, Weronika Chorzempová (Szkoła podstawowa i przedszkole z polskim językiem nauczania w Orlovej (příspěvková organizace): Dla kogo swój, dla kogo obcy? Tożsamość narodowa na Zaolziu, Yelyzaveta Baltyan (Uniwersytet Śląski w Katowicach): Tatarzy krymscy (obcy) autochtoni na swojej ziemi; Sonia Dziadek, Sylwia Mirocha, Kinga Strządała (Uniwersytet Śląski w Katowicach): Sport osób niepetnosprawnych; Agnieszka Cieślar, Marzena Cieślar (Uniwersytet Jagielloński): Psychospołeczne konsekwencje otyłości; Mariola 
Holeksa (Uniwersytet Śląski w Katowicach): Chłopi i szlachta - czyli o inności stanowej; Marlena Stradomska, Karolina Zoszak (Uniwersytet Marii Curie -Skłodowskiej w Lublinie): Wykluczenie społeczne suicydentów z perspektywy psychologicznej; Marlena Stradomska, Karolina Zoszak (Uniwersytet Marii Curie-Skłodowskiej w Lublinie): Spojrzenie na inność w XXI wieku - przyczyny i uwarunkowania ortoreksji; Anton Dragomiletskii (Uniwersytet Śląski w Katowicach): Opozycja jako „Inni” w rosyjskiej przestrzeni publicznej.

II Międzynarodowa Konferencja w Cieszynie zatytułowana: „Pytania o Inność. Inny w moich oczach, Ja w oczach Innego" stanowiła cenną okazję do zapoznania się z wątkiem przewodnim konferencji w wielu różnych płaszczyznach. Sama liczba sekcji tematycznych świadczy o szerokiej perspektywie niniejszej problematyki, co potwierdziło, że tytułowy „Inny” może być oraz jest wszędzie, w zależności od tego, jak go zdefiniujemy. Pogłębione pytania w czasie przerw oraz pogłębiona refleksja zarówno słuchaczy, jak i prelegentów nad niniejszą problematyką udowodniły, że stanowi ona istotny element pracy teoretyków oraz praktyków, a obecność tak szerokiego grona zainteresowanych z wielu ośrodków akademickich w Polsce oraz uczelni zagranicznych jest dowodem na to, że jest ona wszechobecna, a dla organizatorów stanowi impuls motywujący do jej kontynuowania w przyszłości. 